\title{
Effective Management and Its Impact on Growth of Small and Medium Sized Pakistani Firms
}

\author{
Muhammad Zulfiqar \\ MS Business Administration National University of Modern Languages (NUML) Islamabad, Faisalabad Campus \\ Khalid Jamil \\ MS Business Administration National University of Modern Languages (NUML) Islamabad, Faisalabad Campus \\ Muhammad Kashif Khurshid \\ Lecturer Department of Management Sciences National University of Modern Languages (NUML) Faisalabad \\ Campus
}

\begin{abstract}
The study is held to observe the impact of Management including Management levels and decision making on the growth of small firms. Study area is Punjab (Pakistan). Small firms have no proper firm structure; they do not follow the formal rules to run the organization. Inspite of this, these firms are growing rapidly. If these firms have effective management levels and rational decision making than the firms will grow rapidly. The results show a significant increase in growth by using rational decision making and having effective management levels. Statistical results show that if we spend $1 \%$ on independent variable, then it shows an $80 \%$ increase in dependent variable.
\end{abstract}

Keywords: Small firm; Management; Growth; Decision making

\section{INTRODUCTION}

\subsection{Background of Management}

In The Global World of Today the Crucial Importance of Management Cannot is ignored. Better Management is considered as a Magic to cope up with the worst situation. Better Management consultancy have the power to change the worst situation into desired. Simply Management is defined as the process of coordinating and overseeing work activities of others, so that they can accomplish their goals efficiently and effectively. Efficient and effective ways comprise the work should be done properly and on time. The definition of management focuses on two things:

- Co-ordination;

- Over-seeing.

The above two are the main functions performed by the management. Controlling the above two factors efficiently and effectively makes the magic possible to be done, to cope up the worst situation. If an organization have coordination between the employees and also the work activities, and also have the better supervision, than it can accomplish all types of goals easily (Robinson, Pearce, Voziks \& Mescon, 1984).

The importance of management functions cannot be ignored in management. All the four management functions are the life blood of the organization. They provide specific pathway to the organization to run properly i.e. Planning, Organizing, Leading and Controlling.

These functions are the Guidelines to properly run the organization toward achieving its goals. Talking about management is insufficient without a person; who coordinates and overseas the work activities of others; The Manager, who performs all the management activities. There are three levels of management to run an organization properly. All levels of management perform different management functions described earlier. These levels include Top Level, Middle Level and Lower Level management. Top management deals with the big picture issues of the organization such as making strategies, hiring middle level management, making budget, deal with the outer world etc. Board of directors includes this level. Middle level of management perform the functions like execution of plans for organization, making plans for different units, involve in tracking the junior managers and also play a role in the training of lower management. It includes branch managers etc. Lower management involves in assigning the work activities to workers and employees, and also responsible for quantity as well as quality production.

\subsection{Growth}

Number of Researchers answered the question. Edith Penrose defined the growth in two connotations; first the term growth shows the increase in amount e.g. when we speak increase in "output, export and sales" and secondly when the growth in size is observed, it can be the increase in quality of work processes, products etc. Delmar, Davidson observed the heterogeneity of growth as sometimes they observed the change in size, amount, quality, processes etc. commonly we can define the growth "Development over time". The development can be 
observed in management activities, entrepreneurial activities, resources, market characteristics etc. (Davidsson \& Hoing, 2003). Now let's have a glance at small organizations; another important factor of our study. Different researches show different views about small firms (Abor \& Quartey, 2010).

The focus of our research is small firms. We have observed the impact of management on the growth of small firms. For this we should be fully aware of small firms. Different researchers observed the characteristics of small firms. Small firms are more creative (Capellars, Mole, Greene \& Storey, 2008). Small firms are more flexible than large (Chandler, Hoing \& Wilkund, 2005). Due to small number of employees, decision making is quick (Chan \& Foster, 2001). Small firms have limited Resources (Cohen \& Musson, 2000) face uncertainty, do not plan, bad attitude toward detailed day to day procedures (Churchill 1992). Small firms have simple management structure. Manage conceptual aspects less ably than larger firms (Capelleras \& Rabitino 2008).

In our research our focus is small firms with 10 to 99 employees. Now the question raised that why some firms grow more than others? A study of Federico, Kantis, Rabitino (2010) raised the same question and present the findings that from last twenty years, we still have not the clear answer of the phenomenon (Capelleras \& Rabitino, 2008). However, in their study they tell one reason that the different studies did not choose the right variables for explanation. MacPherson and Holt, (2006) supports the argument and further explains the reason of low growth as lack of knowledge, managerial skills, resources etc. Management and growth both are inter related and the above studies reveals that a firm cannot grow until it has splendid management adjustments. Lot of research is done in this scenario and the theme of all the researches is same as small firms are the life blood of the economy (MacPherson \& Holt, 2006). Small firms support the economy of a country more than larger firms.

Research of Abor and Quartey (2010) in Ghana showed that 90\% organizations are small organizations. All the above studies prove that small organizations play a crucial role to boost the economy of a country. We also observed from the previous studies that without proper managerial activities growth has no meaning in organizations. The concept of management is not limited toward management skills rather it has strong relations with Marketing, HRM, managing change and financial activities. Other activities that affect growth are entrepreneurial activities, environment and culture (Bowman \& Swart, 2007). When we observe growth in Entrepreneurship, we come to know that it has a huge impact on growth or growth cannot be imagined without it. It enhances growth by bringing creativity and innovation. When we observe growth in marketing point of view than we come to know here we can grow by managing horizontal, vertical type growth over time (Deakins, 2001).

In HRM previous studies consider the more important capital to human capital. But in small firms, due to limited resources it is not well managed. When we observe the growth in terms of financial point of view, we observe that finance is the major factor, considered more important in small firms. Our focus of study is South Punjab, which is considered the backward area of the country, having low literacy rate, so here growth is mostly taken in sense of monetary terms and we also know that the ultimate objective of a business is profit so; in our proposed research. We took growth in terms of financial performance. But as we explained earlier that growth is development over time so other factors cannot be ignored. Development includes all the factors that are extended over time such as number of employees, number of customers, all assets of the firm etc. If all these factors are increasing over time than we can say that our organization is growing with the passage of time. More growth shows more demand, and more demand enhances the sale and ultimately more profit. Number of researches has done in these prospects, but there are several matters that can be discussed. During this research survey, surveyed a large number of small firms and asked their history to their owners. Researchers cannot explain the detail of all the firms in this study but am eager to explain some of them. Researchers surveyed a firm of shoes in the rural area of Multan, earlier it was started as a non-serious business by a lady just to keep herself busy. The lady was a widow with her three married children. She has a lot of spare time, so she went to a common market and purchase ten shoes for further sale. Earlier profit decided was just to cover the expenses of her fair of transport and little refreshment. But as she started, the demand increases on daily basis. With the passage of time the shoes became famous to the near areas of her home. So, she upgraded her business by including the women's of near areas in her business. As the business flourished, profit and demand also increases. In short, now days her business has become like a small firm. It has proper customers, consumers, suppliers etc. But still this business is running on local rules, with no specific management but a proper increase in growth can be observed. All the decisions regarding extensions, supply, etc. are still taken by the owner lady. There is no specific name suggested for the business, but there are 55 employees working for the business now days.

\subsection{Research problem}

The study is conducted in backward areas of Punjab. The small firms of south Punjab are growing day by day and have a meaningful impact on growth of the economy, but the basic culture of these firms is not so well developed. The owners or employees of the firms are not well educated, so researchers a lot of problems in collecting data from them. Mostly they are not fully aware of the formal terminologies of management, 
researchers tried our level best to clear the terms and to get the pure data. So, it might be a chance of some impure data in the study. But it will be in a little quantity that can be ignored.

\subsection{Purpose of Study}

Small firms know little about financial management and decision making and also lack of planning and development. So we are trying to high light the role of management toward the financial performance of small firms of South Punjab. Our research differs from the previous researches in the sense that previous researches were done on the strong economies; and in Pakistan in big cities. Our focus of research is the backward areas of South Punjab. The study is limited toward small organizations and in some rare situations micro firms and family owned businesses.

\section{LITERATURE REVIEW}

Previous studies also support the findings that we are going to done. But we have observed the fact that the literature on our topic is limited, and there is still enough space to research. Badger, Cheston, Hampson and Smith (2003) said that businesses require both Entrepreneurship and Managment. They defined the Entrepreneurship as focusing on "profitability and Growth seeker", the person who takes the risk to promote the business. On the other hand, a manager is a person who saves the cash to use in future considerations. So, the small organizations, due to limited resources, have a manager. Mostly management in small businesses relates with ownership. Small firms mostly focuses on owner manager, so they know little about financial management, Decision making and entrepreneurship's in this research the researcher mostly focus on financial management decision making. In small firm's decisions are mostly taken on day to day and fire flight basis, so strategic planning toward has no meaning. Small firms have no cash management strategies, however they have owner manager and transactions are usually recorded on day to day basis, so expenditure and cost is fully known, therefore tight cash control is present that helps in their survival.

Grablowsky (1984) argued that stock control difference between large and small companies. Large companies use statistical methods while small companies use Judgment (6\%), Anticipation (32\%), past experience $(15 \%)$, with no methods $(27 \%)$. Wilson said that small firms face liquidity problem, short term funding and banks give them short term loans (Dutta \& Crossan, 2005). Furthermore, he argued that small firms can grow either by organic or acquisition means. Delmar and Wilkins (2002) told the role of small business managers, growth motivations, taking into account the important effects of previous motives and feedback from earlier performance we hypothesize that small firm's managers growth has a unique influence on firm outcome, measured as growth in sales and in number of employees.

Pout Ziouris argued that in growth process, behavioral issues are also very important e.g. the behavior of the management toward an unstructured problem. He also reflects the agency problem in small organizations "a situation in which management goals are proffered over organizational goals", a big hurdle toward the attainment of growth. Federico, Kantis, Raitino said that unfavorable business conditions are the results of culture differences, entrepreneur profile, low firm resources and market characteristics (Honing, 2001).

Firm that has maximum tangible and intangible resources, financed by external resources exhibits higher employed growth. Presence of large and more specifics networks contribute positively subsequent venture growth. Facing high competitors, high growth exports activities and firm's employed, a firm will attain high growth. Chio and Shepherd, Persn and Grant and Lefebvre et al. all argued that organizational technologies compliant and support but remained influenced by decision making and technical ability (Simon, McMillian \& Woodruff, 2002).

Gregory reflects a research from Romania and explained that in Romania it is accepted that small firms represent a key factor of economic growth. Development is the percentage of workforce hired (Mcpherson, 1996). The power of a company is reflected in the number of employees. Also focuses on high performance work system e.g. assessment, training, development and improvement of communication. High risk of failure limits the small firms to grow, as survival is their main concern. At least four parameters have to be supervised in order to obtain stable level of financial standing e.g. percentage of the work cost in added value, profitability, liquidity and solvency.

\subsection{Management}

In this research model we took management as independent variable. In management we observed two main factors e.g. management Levels e.g. top, middle and front line management. We observed the role of these management levels in small firms, and their impact is observed on the growth of small firms. Our next independent variable is Decision making. Decision making is a thought process of choosing the right option from different alternatives. We do forecasting between the cost and benefits of different alternatives, and choose the best one. In our research we observed the behavior of small firms toward decision making. There are two styles of decision making; Centralization and Decentralization (Mintzberg, 1994). In centralization the important 
decisions of the firms are taken by either top management or the owner of the firm. Weather Decentralization involves every employee of organization in decision making. Mostly the European and other countries follow decentralization, but in Pakistan most preferred style is centralization. Most previous researches focuses on small firms of developed areas, where every decision is taken on the basis of already defined rules, but our focus is small firms of south Punjab. So we observed some different behaviour (Schwenk \& Sharader,1993). Moreover, previous literature mostly takes decision making in sense of entrepreneurship, but we observed the behavior of small firms toward decision making toward Centralization and decentralization. We observed the behavior of small firms in our study, these firms have no specific management structure, and most firms have the owner as a top manager, so researcher observed Centralized and decentralization behavior alternatively. The businesses are small and most of the firm have less or no qualified employees, so automatically decision making is decentralized mostly but some firms have owner as top management, so in these firm's decisions are taken by the owner (Sexton \& Van, 1982). But researchers observed a sharp growth in these firms. As we took the example of the shoe business of a lady, the business grows in a short period of time and also growing day by day. We observed the positive impact of management levels on growth. So our profit is increased by involving different management levels in our business, and also by positive decision making.

\subsection{Growth}

In our research we took Growth as Dependent variable. As our focus is backward areas of south Punjab, where small firms mostly see growth in terms of financial performance, that's why our focus is also profitability. But as we defined growth as Development over time, so by increase in profit the assets as well as all other factors will show development. There are number of researches in this scenario, but there are a lot of factors that must be defined. The literature on these variables not enough to cover all the prospects, the variables that we took are short in supply in previous studies, so we took these variables to take the next step, that is useful to highlight the behavior of small firms of south Punjab.

\section{RESEARCH METHODOLOGY}

\subsection{Research technique}

The study used both qualitative and quantitative measures. Due to presence of quantitative data, Financial and statistical tools are also used.

\subsection{Study area}

The study area is the areas of south Punjab, where small firms are present. The study focuses on the impact of management activities on financial activities of small firms.

\subsection{Conceptual Framework}

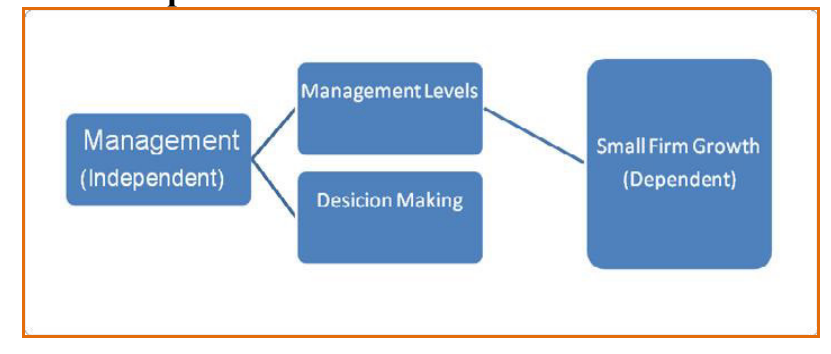

\subsection{Population}

Population is the employees and owners of the small firms.

\subsection{Methods of data collection}

Data is collected both by qualitative and quantitative means. It includes both primary and secondary data. Primary data is conducted through observation, surveys, interviews, Questionnaires etc. Secondary means are internet and previous researches. Secondary means are internet and previous researches (Tables 1 and Table 2).

\section{DATA ANALYSIS}

Data is analyzed by using the software of "SPSS" to get the better results (Table 3).

Table 1: Model summary analysis.

\begin{tabular}{|l|l|l|l|l|}
\hline \multicolumn{4}{|l|}{ Model Summary } \\
\hline Model & R & R Square & Adjusted R Square & Std. Error of the Estimate \\
\hline 1 & $.916^{\mathrm{a}}$ & 0.79 & 0.77 & 0.31245 \\
\hline
\end{tabular}

apredictors: (Constant), effect. management and dm. 
Table 2: ANOVA analysis.

\begin{tabular}{|c|c|c|c|c|c|c|}
\hline \multicolumn{7}{|c|}{ ANOVA* } \\
\hline Model & & Sum of Squares & Df & Mean Square & $\mathbf{F}$ & Sig. \\
\hline \multirow[t]{3}{*}{1} & Regression & 11.753 & 1 & 11.753 & 140.293 & $.000 * *$ \\
\hline & Residual & 2.143 & 23 & 0.092 & & \\
\hline & Total & 13.896 & 22 & & & \\
\hline
\end{tabular}

*Dependent Variable: firm. Growth

**Predictors: (Constant), effect. management and d.m.

Table 3: Coefficient data values.

\begin{tabular}{|c|c|c|c|c|c|c|}
\hline \multicolumn{7}{|c|}{ Coefficients $^{\mathrm{a}}$} \\
\hline & \multirow[t]{2}{*}{ Model } & \multicolumn{2}{|c|}{$\begin{array}{c}\text { Unstandardized } \\
\text { Coefficients }\end{array}$} & \multirow{2}{*}{$\begin{array}{c}\begin{array}{c}\text { Standardized } \\
\text { Coefficients }\end{array} \\
\text { Beta }\end{array}$} & \multirow[t]{2}{*}{$\mathbf{T}$} & \multirow[t]{2}{*}{ Sig. } \\
\hline & & B & Std. Error & & & \\
\hline 1 & $\begin{array}{c}\text { (Constant) } \\
\text { Effective } \\
\text { management }\end{array}$ & $\begin{array}{l}0.955 \\
0.823\end{array}$ & $\begin{array}{l}0.363 \\
0.059\end{array}$ & 0.917 & $\begin{array}{r}2.176 \\
11.432\end{array}$ & $\begin{array}{c}0.014 \\
0\end{array}$ \\
\hline
\end{tabular}

${ }^{a}$ Dependent Variable: firm growth.

to Large firm in a very short period of time. If a firm involve all the three levels of management (Top, Middle, Lower) in every decision of its firm than the projects of the firm will be successful, its profit will increase and ultimately the firm will develop on a daily basis. If a firm is started with a minimum investment, No or little assets, One or small employees than it is not necessary that it will remain in this condition whole its life. If the decisions regarding all the matters of the firm will took wisely by involving all its employees, than there are chances that the firm will grow rapidly. During the whole research, and surveys, and also the Questionnaires that are filled by the employees and owners of small firms, researchers observed positive behaviour between dependent and independent variables. It shows that the results are highly significant. It means if the Management layers of a firm are effective as well as Decisions are taken wisely than the firm will surely grow. Results of the study are showing positivity. A reasonable growth can be observed by rationally controlling the independent variable. The firms that were not showing a reasonable increase in growth were failed to control the independent variable. These firms have not an effective management layers and also lack rational decision making. So according to my study, the firm that is willing to grow should have effective management structure and rational decision making. The importance of human capital cannot be ignored in any organization weather it is small or large, If the potential persons will be present than automatically they will take the decisions that are favourable for the organization, so on the behalf of these persons the firm show positive and intensive growth. The statistical data possess significant influence among effective management levels and rational decision making for the growth and productivity of small firms. In accordance to finding, effective management levels and rational decision making and firm growth are statistically significant at .000 (>.005) and effective management and decision making coefficient is 0.82 , it reveals that if we invest $1 \%$ on independent factor like management level and decision making, it will give return more than $80 \%$ which is greater than others. So firms must put more efforts for effectiveness in managerial levels by hiring potential and productive personnel and also by making rational decisions for firm growth.

\section{CONCLUSION}

As we are observing the behavior of small firm's growth toward their Management, we mostly focus the Management levels and Decision making, but the role of whole effective management cannot be ignored in this regard. If our management will be effective than we observe a huge growth in the small firms. So, if a firm has Effective management layers and also take decisions that are effective and wise (according to the situation) than the firm will grow at a broad level and it is the possibility that it will change its status from small.

\section{REFERENCES}

Abor J, Biekpe N (2006) Small Business financing initiatives in Ghana problems and perspectives in management 4: 69-77.

Abor J, Quartey P (2010) Issues in SMEs in Ghana and south Africa international Research. Journal of finance and Economics 39: 218-228.

Alvarez S, Busenitz LW (2001) The Entrepreneurship of resource based theory. Journal of Management 27: 755 775.

Ashok R, John TS, Jostrom. Is Grameen Lending efficient? Repayment incentives and insurance in village Economies. Review of Economic Studies 7: 21. 
Bowman C, Swart J (2007) Whose Human Capital? The challenge of value capture when capital is embedded. Journal of Management studies 44: 488505.

Capellars JL, Mole K, Greene F, Storey D (2008) Do more heavily regulated economies have poorer proforming new ventures? Evidence from Britian and Spain. Journal of international Business studies 39: 688-704.

Capelleras JL, Rabitino R (2008) Individual, Organizational and environmental determinants of new firm employment growth: Evidence from Latin America. International Entrepreneurship Management Journal 4: 79-99.

Carland, Wcarland J (1998) A productivity for Entrepreneurship: A comparison of Entrepreneurs, small Business owners, and corporate Managers. Journal of Business Venture 14: 89-214.

Chan S, Foster M (2001) Strategy formulation in small Business, The Hong Kong Experience. International Small Business Journal 19: 56-71.

Chandler G, Hoing B, Wilkund J (2005) Antecedents, Moderators and Performance consequences of membership change in a new venture teams. Journal of Business venturing 20: 705-725.

Churchill NC (1992) Research issues in Enterepreneurship. In the state of the art of E.Ed. 13. Sexton DL, Kasardra JD. Mass: PWS-Kent, Boston 579-596.

Cohen L, Musson G (2000) Enterepreneurial identities: Reflection from two case studies. Organization 7: 31-48.

Davidson P, Achtenhagen L, Nolad L (2006) What Do We Know about small firm growth? In parker S, The lifecycle of Entrepreneurial Ventures. International Handbook Series On Enterepreneurship. New York: Springer 361-398.

Davidsson P, Hoing B (2003) The role of social and human capital among nascent entrepreneurs. Journal of Business Venturing 8: 301-331.

Davidsson P, Kirchhoff B, Hatemi JA, Gustavasson H (2002) Empirical analysis of Employment Growth factors using Swedish data. Journal of Business Management 40: 332-349.

Deakins D (2001) The Financial Management of the small Enterprises. Certified Accountants Educational Trust, London.

Delmar F, Shane S (2003) Does Business planning facilitate the development of new ventures? Strategic Management Journal 24: 1165-1185.

Dutta DK, Crossan MM (2005) The Nature of entrepreneurial opportunities: Understanding the process using the 4i organizational learning framework. Enterepreneurship Theory and Practise 29: 425-449.

Floren H, Tell J (2004) The Emergent pre-requisites of managerial learning in small firm networks. Leadership and organization development Journal 25: 292-307.

Grablowsky BJ (1984) Financial management of inventory. Journal of small Business Management.

Honing B (2001) Human capital and structural up heaval: A study of manufacturing firms in the west Bank. Journal of Business Ventures 16: 575-594.

Jones O, Macpherson A (2006) International organization learning and strategic Renewal in SMEs: Extending the $4 \mathrm{i}$ network. Long Range planning 39: 155-175.

Kakati M (2003) Success Criteria in high-tech new ventures. Technovation 23: 447-457.

Karagozoglu N, Lindell M (1998) Internalization of small and medium-sized technology-based firms, An Exploratory study. Journal of small Business Management 36: 44-59.

Kohli AK, Jaworski BJ (1990) Market Orientation: The construct Research Propositions, and Managerial Implications. Journal of Marketing 54: 1.

Macpherson A, Holt R (2006) Knowledge, learning and small firm growth: A systematic Review of the Evidence 36: 172-192.

Mcpherson M (1996) Growth of Micro and small enterprises in southern Africa. Journal of Development Economics 48: 253-277.

Mintzberg H (1994) The fall and rise of strategic planning. Hayward Business Review 72: 107-114. 33. Posner BG (1985) Real enterepreneurs don't plan 7: 129-132.

Reschke CH, Sascha K (2005) Strategy and Strategic management process of social evolution: An introductory overview over relevant perspectives. Paper presented at the BAM conference Oxford.

Robinson RB, Pearce JA, Voziks GS, Mescon TS (1984) The Relationship between stage of Development and small firm planning and performance. Journal of small Business Management 22: 45-52.

Rue LW, Hara NA (1998) The relationship between planning and sophistication and performance in small Businesses. Journal of small Business Management 36: 24-32.

Salder-Smith E, Hampson Y, Chaston I, Badgar B (2003) Managerial behaviour, Enterepreneurial style and small firm performance. Journal of Business Management 41: 47-67.

Schwenk CR, sharader CB (1993) Effects of formal strategic planning on financial performance in small firms: A Meta-analysis Enterepreneurship Theory and Practice 17: 53-64.

Sexton DK, Van Auken P (1982) Prevalence of strategic planning in small Businesses. Journal of small Business Management 20: 6-20. 
Shane S (2000) Prior knowledge and discovery of entrepreneurial opportunities. Organization science 11: 448469.

Shepered D, Wilkund J (2009) Are we comparing Apples with apples or apples with oranges? Appropriatness of knowledge accumulation across growth studies. Entrepreneurship theory and practice 33: 105-123.

Simon J, McMillian J, Woodruff C (2002) Property Rights and Finance. American Economics Review 92: 1335 1356.

Zacharakis A, Meyer G (1998) A lack of insight: Do venture capitalists really understand their own decision process. Journal of Business Venture 13: 57-76. 